\title{
Perceived Price and Organic Food Consumption Behaviour
}

\author{
Mahrinasari MS ${ }^{1}$ \\ $\left\{\right.$ pr1nch1t4@yahoo.com $^{1}$ \} \\ Faculty of Economics and Business, University of Lampung, Indonesia ${ }^{1}$
}

\begin{abstract}
This research aims to analyze the organic food consumption behaviour of the consumers, measured by utilitarian and hedonist behaviour, due to the perceived price effect to trigger consumers' purchase intention. To address this objective, a quantitative research design has been implemented by distributing the questionnaires. 347 usable data were analyzed by using SEM-based Covariance. The research results show that perceived price has a positive significant effect on utilitarian and hedonist behaviour, and then the utilitarian and hedonist also affect purchase intention. However, purchase intention is directly much more determined by perceived price than utilitarian and hedonic behaviour. Even though, the high price in this research is less barrier, the research results imply that the company management of the organic product must create, offer, and deliver the high quality of the organic products within the competitive price to boost the purchase intention improvement of the consumers.
\end{abstract}

Keywords: Organic Food, Perceived Price, Utilitarian, Hedonist, Purchase Intention

\section{Introduction}

The organic food consumption has exponentially increased in the last two decades. If compared to the conventional food, the organic food growth number is higher [1], due to the improvement level of consumer awareness on food safety and health concern [2], and also the environmental concern [3]. The organic food is defined as the produced products with free of pesticides, synthetic fertilizers, bioengineering, and ionizing radiation [4]. [5] define the organic food is a food guaranteed produced, stored, and processed with free synthetic fertilizers and chemicals, and also cultivated through an environmentally friendly process [6].

The growing demand of the organic food also exists for Indonesian consumers but there are still several consumers reluctant to buy the organic product due to the higher price of the organic food than of the non-organic food [7], even though, 18 percent of Southeast Asia's consumers have willingness to pay more toward organic food [8]. Therefore, the price of organic food is an obstacle due to additional production costs, as stated by [9], [10]. Willingness to pay as an indicator of perceived price [11], [12] needs to be examined due to the main obstacle for organic food consumption [13]-[15]. Meanwhile, perceived price is a predictor of purchase intention, as the findings of [16], stating that the higher price, the higher purchase intention will be created. Meanwhile, [17] found that perceived price affected a negative significant on utilitarian and hedonic behaviour so that the higher perceived price toward organic food is, the less positive purchase intention will be. Furthermore, [17] stated that the higher perceived price discourages consumers to get utilitarian and hedonic benefits of buying organic food. In addition, [3] research' finding 
showed that price can encourage Hedonist and Utilitarian Behavior so that the organic food consumption is expected to be high, even though the estimate values are still lower. The estimate values of the price effect on Hedonist behavior is $11,70 \%$, and the estimate values of its on Utilitarian effect is $0,10 \%$. Therefore, this research aims to analyze the consumers' organic food consumption behaviour, measured by utilitarian and hedonist behaviour, due to the perceived price effect to encourage consumers' purchase intention.

\section{Literature review}

Consumers in the worldwide recently are aware toward organic food consumption due to healthy concern, beliefs toward the good taste of the organic products, and also the environmental concern [2], [3]. The consumers need organic food without pesticides, synthetic fertilizers, bioengineering, and ionizing radiation, and also chemical contains [5], [6], or contains natural ingredients. Consumers are increasingly concerned about nutrition, health and the quality of their food (Gil, 2000). Then, [18] stated that the increase of the consumer awareness toward the health and nutritious value of food has increased the demand for organic food consumption.

However, the higher price of the organic food is the main barrier toward the organic food consumption [19]-[21], due to the value differences with the conventional food alternatives. Organic food consumption represents the consumer behaviour in buying and consuming the organic products. Therefore, this research adopts the consumer behaviour theoretical concept in terms of the Theory of Reasoned Action/TRA) and the Theory of Planned Behavior/TPB [3], [17], [22], referring to the S-O-R model [28], showing that Perceived Price represents Stimuli, Utilitarian and Hedonic behaviour as organism, and Behavioural Intention as response. TRA developed by [23] and TPB developed by [24] have the main assumption that the people in their decision-making process and behavioural actions are rational [25]. TRA has been used to examine buying behaviour in green products [26], [27].

\subsection{Perceived Price, Utilitarian, and Hedonic Behaviour}

The traditional economic theory views price as a monetary value needed to make the products purchase. [29] noted that a higher price increases an economic cost perception, and then it negatively affects product evaluations and purchase intentions. Furthermore, [14] stated that the price plays a role as a measure of sacrifice in purchasing organic food, but a high price of organic food is a major barrier [15]. The higher consumers perceive the cost of organic food, the less behaviour toward the purchase of organic food.

Moreover, the utilitarian and hedonic behaviour represent the consumers values. In terms of utilitarian behaviour, the consumers assess how useful buying organic food is, while in terms of hedonic behaviour, the consumers treat buying and consuming the organic food as the daily pleasant and enjoyable activity [17]. In other words, the utilitarian behaviour is concerned with the functional values of the organic food, while the hedonic behaviour focuses on emotional gratification or sensory experiences [30]. Hedonic behaviour draws the values of joy, entertainment, happiness for individual and social benefit [31]. Meanwhile, the research finding of [32] explored that organic food consumption aims not only to get nutritional benefit, but also to get happiness and joy.

[33] suggested that the perceived price is a predictor of the utilitarian and hedonic behaviour. Other researchers [34], [35] found that the utilitarian and hedonic behaviour provoked the buyers to pay a low price or price savings of the products. While, based on economic utility theory, the utilitarian behaviour needs the price saving. Also, the hedonic 
behaviour, such as a sense of excitement, accomplishment, and pride, are looking for a low price [17]. Therefore, the author hypothesizes that:

Hypothesis 1. The perceived price will have a significant negative effect on utilitarian behaviour toward the purchase of organic food.

Hypothesis 2. The perceived price will have a significant negative effect on hedonic behaviour toward the purchase of organic food.

\subsection{Utilitarian, Hedonic Behaviour, and Purchase Intention}

[24] stated that the consumer behaviour measured by the consumers' attitude can predict the purchase intention toward the products. In this research, utilitarian and hedonic behaviour can determine purchase intention toward the organic food. Referring to [36], hedonic behaviour can positively affect the purchase intention. [37] defined purchase intention is the consumers intention to buy the products or services after evaluating the products attributes, included the price. Referring to [25], there is a positive effect of consumer attitudes, included the utilitarian and hedonic behaviour effect on purchase intention. Therefore, the following hypothesis is that:

Hypothesis 3. Utilitarian behaviour will have a significant positive effect on purchase intentions of organic food.

Hypothesis 4. Hedonic behaviour will have a significant positive effect on purchase intentions of organic food.

\subsection{Perceived Price and Purchase Intention}

Perceived price is a predictor of purchase intention [16]. One of perceived price measurement is a willingness to pay the premium price of the products. In the context of organic food, [8], [11], [38] found that consumers have willingness to pay the premium price of the organic food due to a higher degree of environmental concerns, based on the social identity theory [39]. A high degree of environmental concerns tends to create a positive evaluation of a company's green initiatives, leading to a willingness to pay premiums price for green initiatives or green products, included organic product [40]. [41] found that U.S. restaurant customers who have environmental concerns are willing to pay the prices up to $10 \%$ or higher for green practices, event though, [42] found that most consumers have little consideration for ethical initiatives of a company when making purchase decisions. Therefore, a customer who has more environmental concerns is more likely to purchase green products to satisfy a customer value. The fifth hypothesis is:

Hypothesis 5: Perceive price has a positive significant effect on purchase intention

All those hypotheses can be drawn in the proposed research model (Figure 1).

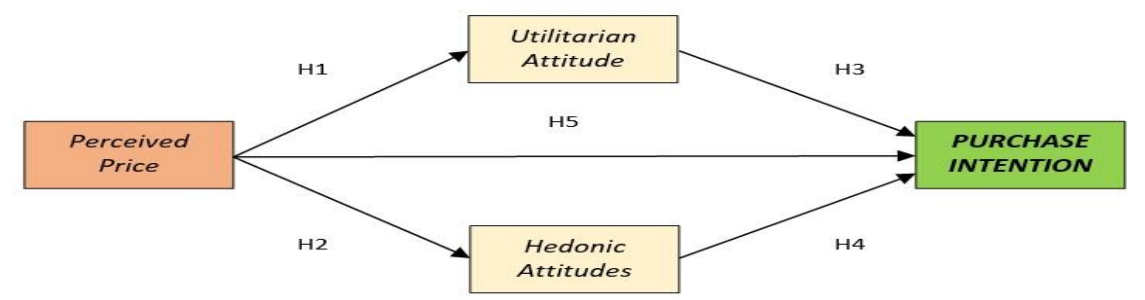

Fig. 1. Research Framework 


\section{Methodology and Data Analysis}

The research design applied a quantitative research design by distributing the online questionnaires (google.form) to 400 Indonesian potential consumers who know and understand organic food benefit for the sake of health, safety, and environmental concern, as the purposive sampling implementation. 347 usable data were analyzed by two step approach of SEM-based Covariance (Anderson dan Gerbing, 1988). first is to measure the model fit, and second is to get the structural model [43], [44].

The measurements of the Purchase Intention adopted [45]. The measurement of the utilitarian and hedonic behaviour adopted [46]. The perceived price measurements adopted [11], [12], and also taken from [3]. All item measurements are valid and reliable, based on Construct Validity test shown by the factor loading score more than 0.50 [47] and Reliability test results by Cronbach Alpa more than 0.70 [47].

\section{Research Result and Discussion}

The respondent's profile shows the dominating percentage number is females as of $55.33 \%$. While the percentage number of age level (29-44 years old) dominated as of $38.62 \%$, followed by $17-22$ years old $17.00 \%$. If compared to older age (more than 45 years old), the younger dominated as of $66,57 \%$. The younger have the high education level (graduated degree $61.67 \%$ and bachelor degree $26.80 \%$ ), income (more than IDR5.00 million $52.74 \%$ ), and jobs as of 76,66\% (the rest are the student and house wife $23.34 \%$ ).

Based on SEM-Based Covariance under LISREL application 8.80, the model fit is in good fit (Goodness of Fit index/GFI = 0.97; Adjusted Goodness of Fit Index/AGFI = 0.93; Root Mean Square Error of Approximation/RMSEA) $=0.027$; P-Value for Test of Close Fit $=0.99$; Normed Fit Index $(\mathrm{NFI})=0.99$; Comparative Fit Index $(\mathrm{CFI})=1.00$; Root Mean Square Residual $(\mathrm{RMR})=0.021$; and Standardized RMR $=0.029)$. The

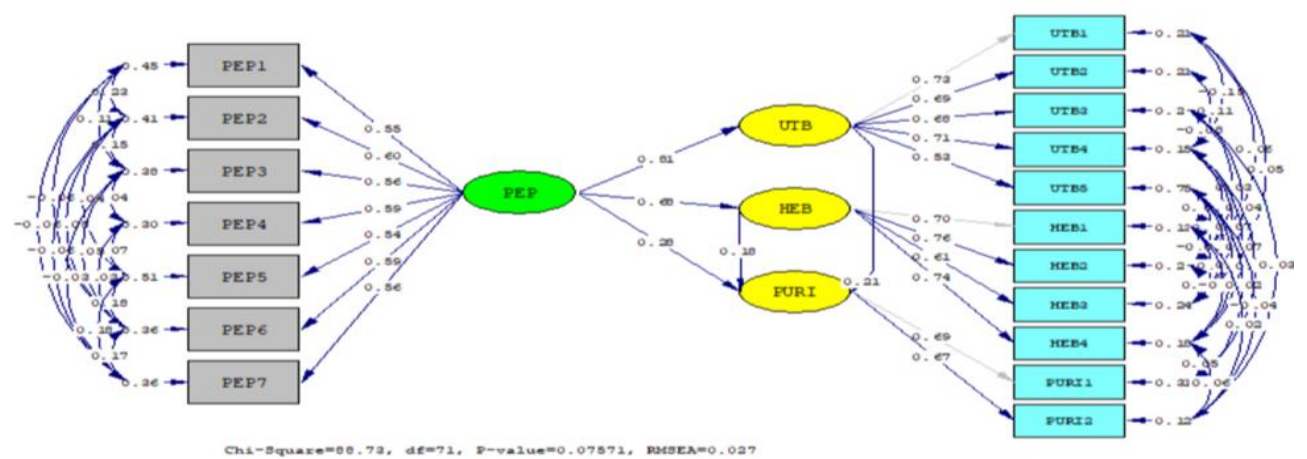

structural model shows that all hypotheses are supported by Data (Figure 2 and Table 1).

Fig. 2. Estimated Model, Based on SEM-Based Covariance, LISREL Application 8.80 Result

Table 1. Hypothesis Decision Results Based on SEM-Based Covariance

\begin{tabular}{|c|c|c|c|c|}
\hline No & Hypothesis & $\begin{array}{c}\text { Standardized } \\
\text { Coefficient }\end{array}$ & $\begin{array}{c}\text { t- } \\
\text { Values }\end{array}$ & $\begin{array}{l}\text { Hypothesis } \\
\text { Decision }\end{array}$ \\
\hline 1. & Utilitarian Behaviour (UTB) $\leftarrow$ & 0.81 & 14,32 & Supported \\
\hline 2. & Hedonic Behaviour (HEB) $\longleftarrow$ & 0.68 & 11.90 & Supported \\
\hline 3. & Purchase Intention (PURI) $\longleftarrow$ Utilitarian Behaviour (UTB) & 0.21 & 2.25 & Supported \\
\hline 4. & Purchase Intention (PURI) $\longleftarrow$ Hedonic Behaviour (HEB) & 0.18 & 1.99 & Supported \\
\hline
\end{tabular}


5. Purchase Intention (PURI)

Perceived Price (PEP)

0.28

7.17

Supported

Table 1 shows that Perceived Price has a positive significant effect on Utilitarian and Hedonic behaviour but the highest estimated value on Utilitarian effect $(81.00 \%)$ rather than on hedonic effect $(68.00 \%)$. However, the results show a positive significant effect, contrary to the research result by [17]. This result supports the findings of [3], [8], [16]. The perceived price effect on utilitarian and hedonic behaviour clearly exposes that organic food consumption exists not only for the sake of satisfaction and good health but also for environmental concerns, as the research results by [3], [16]. Besides, consumers toward organic food consumption are not sensitive toward the high price [48], as long as organic food has a high quality, representing utilitarian consumer behaviour.

Utilitarian and Hedonic behaviour effect on Purchase Intention also show a positive significant effect, even though the estimated value of Utilitarian effect is higher $(21.00 \%)$ than that of Hedonic effect (18.00\%). This finding represents that Utilitarian behaviour effect is the main factor for organic food consumption. The utilitarian customer behaviours need more functional values of the organic food, such as in term of healthy foods or more safety without any kinds of pesticides and chemicals, rather than emotional values as a dimension of consumption values theory such as happiness, joy, enjoyment fun, and pleasure [49], as the measurement of hedonic behaviour.

In addition, Perceived Price directly has a positive significant effect on Purchase Intention as of $28.00 \%$. This estimated value (28\%) is higher, if compared to Utilitarian and Hedonic behaviour effect on purchase intention. This result supports the research results by [8], [11], [38]. It means that more organics food consumption is in need of consumers for healthy and environmental concerns, if referring to theory of consumption values, especially for functional values in term of the food quality devoid of harmful ingredients, nutritional value, natural content, freshness, and health attribute of organic food [49] consistent with utility theory in term of extrinsic values such as price [50]; and social identity theory [39], congruence with social values in term of environmental concerns [49].

\section{Conclusion}

Organic food consumption becomes a need of consumers for meeting more consumers values in terms of functional values, most related to organic food quality and safety representing utilitarian behaviour, social values in term of environmental concerns to regenerate and maintain the green initiatives; and emotional values representing hedonic behaviour of the consumers.

Price of organic food is the main factor to affect Utilitarian dan Hedonic behaviour, and also Purchase Intention. However, consumers of organic food do not care about the high price. The high price is not a barrier especially for Indonesian Consumers right now. The most important think for them toward organic food is the quality of organic food to satisfy their health and environmental consciousness.

\section{Implications/Limitations and Suggestions for Further Research}

Maintaining organic foods free from pesticides and chemicals contains is a duty for the organic food industry. The most important determinant for organic food consumption is nutrition, health, and environmental consciousness. Also, the prices of organic food should be kept affordable for the consumers because the price plays a versatile role to trigger the purchase intention of the consumers. Nutritional Quality content for improving the consumers' health has an influence on Utilitarian behaviour leading the consumers intent to buy. Moreover, price is the main factor to affect Utilitarian and Hedonic behaviour. 
However, the high price for organic food consumers is less barrier in this research, contrary to the previous findings [17], [49]. This happens due to the differences of samples profile and a research design. The finding by [49] implemented mainly a qualitative research design within a systematic literature review by including subjective evaluation and judgement. While the resistant toward the high price as the finding by [17] was caused by using the samples of primary grocery shoppers in the household who had ever purchased organic food. This research used the various profile in terms of the job status dominated by the workers/employees, employers, and entrepreneurs (76.66\%), the job status of house hold just $3.17 \%$. The educational background also is dominated by graduated degree $(61.67 \%)$, having the higher income more than 5 million $(52.74 \%)$, and also Income (higher in between 5 million and 10 million rupiah). It seems that these kinds of socio economic and demography profile are considered as the moderating roles in the effect of perceive price on Utilitarian and Hedonic behaviour, and also Purchase Intention. Therefore, future research should be conducted by examining the moderating role of socio economic and demography profile, such as gender, income, Culture, and life style.

\section{References}

[1] Cushman and Wakefield, "The global food \& beverage market," 2017. .

[2] S. S. Mohamad, S. D. Rusdi, and N. H. Hashim, "Organic Food Consumption among Urban Consumers: Preliminary Results," Procedia - Soc. Behav. Sci., vol. 130, pp. 509-514, 2014, doi: 10.1016/j.sbspro.2014.04.059.

[3] M. S. Mahrinasari, "Impact of safety concerns on a lifestyle," J. Secur. Sustain. Issues, vol. 9, no. 1, pp. 269-280, 2019, doi: 10.9770/jssi.2019.9.1(20).

[4] U. S. D. of Agriculture, "Organic foods production," 2018. .

[5] S. Lockie, K. Lyons, G. Lawrence, and K. Mummery, "Eating 'green': motivations behind organic food consumption in Australia," Sociol. Ruralis, vol. 42, no. 1, pp. 23-40, 2002.

[6] G. Chinnici, M. D’Amico, and B. Pecorino, "A multivariate statistical analysis on the consumers of organic products," Br. Food J., vol. 104, pp. 187-199, 2002, doi: $10.1108 / 00070700210425651$.

[7] K. O. Indonesia, "Gaya Hidup Cerdas dengan Konsumsi Makanan Organik,” 2015.

[8] D. Wahyudi, "Konsumsi Makanan Organik di Indonesia Kian Meningkat.”.

[9] L. Marian, P. Chrysochou, A. Krystallis, and J. Thøgersen, "The role of price as a product attribute in the organic food context: An exploration based on actual purchase data," Food Qual. Prefer., vol. 37, pp. 52-60, 2014.

[10] R. S. Hughner, P. McDonagh, A. Prothero, C. J. Shultz, and J. Stanton, "Who are organic food consumers? A compilation and review of why people purchase organic food," J. Consum. Behav. An Int. Res. Rev., vol. 6, no. 2-3, pp. 94-110, 2007.

[11] K. H. Kang, L. Stein, C. Y. Heo, and S. Lee, "Consumers' willingness to pay for green initiatives of the hotel industry," Int. J. Hosp. Manag., vol. 31, no. 2, pp. 564-572, 2012, doi: 10.1016/j.ijhm.2011.08.001.

[12] A. C. Cakici, Y. Akgunduz, and O. Yildirim, "The impact of perceived price justice and satisfaction on loyalty: the mediating effect of revisit intention," Tour. Rev., vol. 74, no. 3, pp. 443-462, 2019, doi: 10.1108/TR-02-2018-0025.

[13] R. Yadav and G. S. Pathak, "Young consumers' intention towards buying green products in a developing nation: Extending the theory of planned behavior," $J$. Clean. Prod., vol. 135, pp. 732-739, 2016.

[14] S. Padel and C. Foster, "Exploring the gap between attitudes and behaviour: Understanding why consumers buy or do not buy organic food," Br. Food J., vol. 107, no. 8, pp. 606-625, 2005, doi: 10.1108/00070700510611002. 
[15] M. K. Magnusson, A. Arvola, U. K. Koivisto Hursti, L. Åberg, and P. O. Sjödén, "Attitudes towards organic foods among Swedish consumers," Br. Food J., vol. 103, no. 3, pp. 209-227, 2001, doi: 10.1108/00070700110386755.

[16] S. Molinillo, M. Vidal-Branco, and A. Japutra, "Understanding the drivers of organic foods purchasing of millennials: Evidence from Brazil and Spain," $J$. Retail. Consum. Serv., vol. 52, pp. 1-9, 2020, doi: 10.1016/j.jretconser.2019.101926.

[17] H. J. Lee and Z. S. Yun, “Consumers' perceptions of organic food attributes and cognitive and affective attitudes as determinants of their purchase intentions toward organic food," Food Qual. Prefer., vol. 39, no. 2015, pp. 259-267, 2015, doi: 10.1016/j.foodqual.2014.06.002.

[18] K. T. Phuah, T. Golnaz, M. Zainalabidin, and S. Mad Nasir, "Consumers' intention to purchase green food in Malaysia," in International Conference on Innovation Management and Service, 2011, vol. 14, no. 1, pp. 113-118.

[19] P. Bryła, "Organic food consumption in Poland: Motives and barriers," Appetite, vol. 105, pp. 737-746, 2016.

[20] K. Lillywhite, D.-J. Lee, B. Tippetts, and J. Archibald, "A feature construction method for general object recognition," Pattern Recognit., vol. 46, no. 12, pp. 3300-3314, 2013.

[21] M. Yazdanpanah, M. Forouzani, and M. Hojjati, "Willingness of Iranian young adults to eat organic foods: Application of the Health Belief Model," Food Qual. Prefer., vol. 41, pp. 75-83, 2015.

[22] L. Zagata, "Consumers' beliefs and behavioural intentions towards organic food. Evidence from the Czech Republic," Appetite, vol. 59, no. 1, pp. 81-89, 2012.

[23] M. Fishbein and I. Ajzen, Belief, attitude intention and behavior: An introduction to theory and research. Reading, MA: Addison-Wesley, 1975.

[24] I. Ajzen, "From intentions to actions: A theory of planned behavior," in Action control, Springer, 1985, pp. 11-39.

[25] I. Ajzen and M. Fishbein, Understanding attitudes and predicting social behavior. Englewood Cliffs, NJ: Prentice-Hall, 1980.

[26] H. Y. Ha and S. Janda, "Predicting consumer intentions to purchase energyefficient products," J. Consum. Mark., vol. 29, no. 7, pp. 461-469, 2012, doi: $10.1108 / 07363761211274974$.

[27] N. A. Wahid, E. Rahbar, and T. S. Shyan, "Factors influencing the green purchase behavior of Penang environmental volunteers," Int. Bus. Manag., vol. 5, no. 1, pp. 38-49, 2011.

[28] A. Mehrabian and J. A. Russell, "The basic emotional impact of environments," Percept. Mot. Skills, vol. 38, no. 1, pp. 283-301, 1974.

[29] A. R. Rao and K. B. Monroe, "The moderating effect of prior knowledge on cue utilization in product evaluations," J. Consum. Res., vol. 15, no. 2, pp. 253-264, 1988.

[30] R. Batra and O. T. Ahtola, "Measuring the hedonic and utilitarian sources of consumer attitudes," Mark. Lett., vol. 2, no. 2, pp. 159-170, 1991.

[31] J. F. Sherry, "A Sociocultural Analysis of a Midwestern American Flea Market," 1990.

[32] L. Hartley et al., "Increased consumption of fruit and vegetables for the primary prevention of cardiovascular diseases," Cochrane Database Syst. Rev., no. 6, 2013.

[33] H. Mano and M. T. Elliott, "Smart shopping: the origins and consequences of price savings," ACR North Am. Adv., 1997.

[34] B. Babin, W. Darden, and M. Griffin, "Work and/or fun: Measuring hedonic and utilitarian shopping value,” J. Consum. Res., vol. 20, no. 4, pp. 644-656, 1994. 
[35] R. M. Schindler, "The excitement of getting a bargain: some hypotheses concerning the origins and effects of smart-shopper feelings," ACR North Am. Adv., 1989.

[36] R. Davis, B. Lang, and N. Gautam, "Modeling utilitarian-hedonic dual mediation (UHDM) in the purchase and use of games," Internet Res., vol. 23, no. 2, pp. 229256, 2013, doi: 10.1108/10662241311313330.

[37] I. Khan, T. A. Ghauri, and S. Majeed, "Impact of brand related attributes on purchase intention of customers. A study about the customers of Punjab, Pakistan," Interdiscip. J. Contemp. Res. Bus., vol. 4, no. 3, pp. 194-200, 2012.

[38] J. Aschemann-Witzel and S. Zielke, "Can't buy me green? A review of consumer perceptions of and behavior toward the price of organic food," J. Consum. Aff., vol. 51, no. 1, pp. 211-251, 2017.

[39] T. Henri and J. C. Turner, "The social identity theory of intergroup behavior," Psychol. Intergr. relations, vol. 2, pp. 7-24, 1986.

[40] T. J. Brown and P. A. Dacin, "The company and the product: Corporate associations and consumer product responses," J. Mark., vol. 61, no. 1, pp. 68-84, 1997.

[41] K. Dutta, V. Umashankar, G. Choi, and H. G. Parsa, "A comparative study of consumers' green practice orientation in India and the United States: A study from the restaurant industry," J. Foodserv. Bus. Res., vol. 11, no. 3, pp. 269-285, 2008.

[42] M. Carrigan and A. Attalla, The myth of the ethical consumer - do ethics matter in purchase behaviour?, vol. 18, no. 7. 2001

[43] J. F. Hair, R. E. Anderson, B. J. Babin, and W. C. Black, "Multivariate data analysis: A global perspective (Vol. 7).” Upper Saddle River, NJ: Pearson, 2010.

[44] J. L. Arbuckle, “AMOS 18 User’s Guide. SPSS.” Inc Chicago:, 2009.

[45] F. Marticotte and M. Arcand, "Schadenfreude, attitude and the purchase intentions of a counterfeit luxury brand," J. Bus. Res., vol. 77, pp. 175-183, 2017, doi: 10.1016/j.jbusres.2016.12.010.

[46] R. U. Ashraf, F. Hou, and W. Ahmad, "Understanding continuance intention to use social media in China: The roles of personality drivers, hedonic value, and utilitarian value," Int. J. Human--Computer Interact., vol. 35, no. 13, pp. 12161228, 2019.

[47] J. F. Hair, W. C. Black, B. J. Babin, R. E. Anderson, and R. Tatham, "Multivariate data analysis . Uppersaddle River.” NJ: Pearson Prentice Hall, 2006.

[48] M. Janssen, "Determinants of organic food purchases : Evidence from household panel data," Food Qual. Prefer., vol. 68, no. February, pp. 19-28, 2018, doi: 10.1016/j.foodqual.2018.02.002.

[49] S. Kushwah, A. Dhir, M. Sagar, and B. Gupta, "Determinants of organic food consumption . A systematic literature review on motives and barriers," vol. 143, no. October 2018, 2019.

[50] F. An, "Journal of Retailing and Consumer Services The in fl uence of perceived food quality, price fairness, perceived value and satisfaction on customers' revisit and word-of-mouth intentions towards organic food restaurants," vol. 50, no. February, pp. 103-110, 2019, doi: 10.1016/j.jretconser.2019.05.005. 